\title{
Omkring Grundtvig-Selskabets tilblivelse
}

\author{
Foredrag på Liselund 15. januar 1988
}

\section{af Henning Høirup}

Netop i disse dage er det 40 år siden Grundtvig-Selskabet trådte frem for offentligheden. Det konstituerende møde fandt sted i Vartovs konfirmandstue den 13. januar 1948. Dèr realiserede vi ideen om at oprette et frit og åbent forum for Grundtvig-forskningen. Fra mødet udsendtes følgende Ritzau-meddelelse:

På et møde i Vartov i dag er der stiftet et Grundtvig-Selskab, hvis formål er at fremme studiet af N. F. S. Grundtvig, hans virke og hans stilling i åndslivet i og udenfor Danmark. Selskabet agter i lighed med Holberg- og H. C. Andersen-selskaberne at udsende en årbog, "Grundtvig-Studier". Alle interesserede kan blive medlemmer. (Under pressemeddelelsen var de 15 stifteres navne anført).

Når denne officielle kundgørelse udtrykkelig angiver 13. januar 1948 om stiftelsesdato, kan det jo nok undre, at Selskabet altid - og på samtlige udgivelser - bruger benævnelsen: Grundtvig-Selskabet af 8 . september 1947. Denne sidste dato er den rigtige, som jeg senere skal dokumentere; men de seks stiftere vedtog på Ribemødet 8.9.1947 at udvide kredsen med 9 medstiftere og dette skete i Vartov.

I Grundtvig-Studier 1957 (s. 7-24) har jeg berettet om "Grundtvig-Selskabets tilblivelse og virksomhed i dets første tiår ". Her vil jeg genopfriske og supplere mine erindringer. Med gamle mænds hukommelse har det sig jo - som William Heinesen siger - sådan, at "nogle oplevelser bliver stående knivskarpt $\mathrm{i}$ erindringen, mens andre fortoner sig $\mathrm{i}$ halvglemthedens tåge og må forsøges skønsomt gendigtet«. Det sidste vil jeg helst ikke forfalde til! Der er jo nu, efter Steen Johansens død i fjor, kun to i live af de seks, der tog initiativet til at oprette vort selskab i 1947: dr.phil. William Michelsen og jeg. 
Først vil jeg give et par glimt af forhistorien. Da jeg midt $i$ 20 'rne som gymnasiast læste de fleste bind af Grundtvigs "Poetiske Skrifter ", lærte jeg at skønne så meget på hans "lange sjapdigte " (som Poul Martin Møller betegnede dem), at det ærgrede mig, at udgaven var gået i stå, efter Svend Grundtvigs død, med bind 7, der udkom 1889. Først i 1929-1931 fuldførte Georg Christensen udgivelsen med de to sidste bind. Samtidig udgav Ernst J. Borup og Fred. Schrøder "Håndbog i N. F. S. Grundtvigs Skrifter" og Edv. Lehmanns "Grundtvig “ kom også i 1929. Interessen for Grundtvig var altså begyndt at vågne en halv snes år, før den såkaldte "Grundtvig-renæssance» blev indvarslet med Hal Kochs forelæsninger i efteråret 1940.

Som det måske allervigtigste, der skete på den litterære Grundtvig-front i min studentertid, må jeg nævne den 11. udgave af "Folkehøjskolens Sangbog ", med et væld af melodier af Carl Nielsen, Thomas Laub, Oluf Ring og Thorvald Aagaard - dette benådede firkløver, som satte Grundtvigs sange og salmer i toner, som gav dem nyt liv. Deres melodier fik siden, under besættelsen, fundamental betydning - to af Oluf Ring blev ligefrem "slagsange" ved møde efter møde landet over: "Ingen har guldtårer fældet " og "Kun ord, som går i sagn og sang ", den sidste med verset:

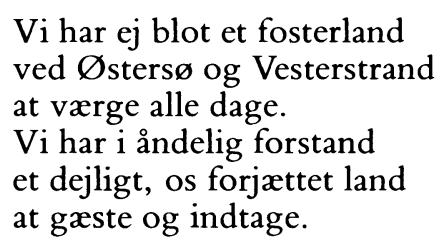

Under dette løsen blev der, i de fem år under besættelsen, i mange præstegårde flittigt studeret Grundtvig. Min nabopræst Kaj Thaning i Asperup imponerede mig ved sit seddel-kartotek over hovedbegreber hos Grundtvig. Drøftede vi mærkelige vendinger i Grundtvigs salmer, f.eks. i "Lyslevende fra Himmerig «:

Lyslevende, trods sten og segl

opstod han fra de døde,

som livets sol af himlens spejl

$\cdots$

med kød og ben $\mathrm{i}$ åndens magt, 
med alt forklaret, alt fuldbragt, opfor han i det høje -

ja, så trak Thaning straks kortet: Kød og Ben frem, med parallelsteder, vi kunne granske. Hans kartotek vil være værdifuldt for den Grundtvig-Ordbog, som bør komme! Vi lånte Grundtvigmanuskripter hjem fra Det kgl. Bibliotek, takket være rigsbibliotekar Svend Dahl, mod løfte om at forvare de dyrebare fascikler i vore brandsikre boxe til kirkebøgerne.

Et initiativ, som i høj grad stimulerede den teologiske Grundtvig-forskning, udgik fra biskop Hans Øllgaard, Odense, som i 1946 og 1947 indbød til "Grundtvigsk Arbejdskonvent " og ledede det fortrinligt på Kerteminde Højskole. Både Thaning og jeg var glade for denne lejlighed til at fremlægge resultaterne af vort slid i studerekammeret til drøftelse med kolleger. Allerede dengang havde Thaning sin tese om 1832 som det store vendepunkt for Grundtvig klar og her forfægtede han sit feltråb: "Menneske først-«, som resulterede i den hidtil største og vægtigste teologiske disputats (1963). Det var også her, jeg forelagde min "mageløse opdagelse" af den betydning, som Grundtvig tillagde "Modsigelsens Grundsætning " som ledestjerne for sin tænkning. Det gav anledning til, at biskop Øllgaard tilskyndede mig til at søge orlov og skrive disputats i sommeren 1947.

Andre end vi var i 40'rne i fuld gang med kildestudier af Grundtvig. I Det kgl. Bibliotek lærte jeg tre energisk engagerede unge litteraturforskere at kende. Først William Michelsen, der da var dansk lektor ved Uppsala Universitet. Han sad en dag ved pulten til højre for mig, og vi opdagede, at vi begge rekvirerede næsten de samme manuskripter til brug ved studiet af Grundtvigs tidsskrift "Danne-Virke".

Kontakten var øjeblikkelig etableret. Vor første debat i kaffepausen fortsattes i stadig udveksling af synspunkter og førte til, at vi - $\mathrm{i}$ stedet for at "overlappe" hinanden - afstak "territorier" for vor forskning: han koncentrerede sig om "Tilblivelsen af Grundtvigs historiesyn " (titlen på hans disputats 1954), medens jeg samlede mig om "Grundtvigs Syn på Tro og Erkendelse" (1949).

Kort efter traf jeg to andre cand.mag.er, der uophørligt granskede Grundtvigs forfatterskab og de over 500 pakker med hans 
håndskrifter: Steen Johansen, der med jernflid var begyndt arbejdet på sit hovedværk "Bibliografi over N.F. S. Grundtvigs Skrifter" og Helge Toldberg, der var langt fremme med sin undersøgelse af "Grundtvig som filolog" (1946), og som nu, i vore hyppige samvær, afgrænsede sit gebet: "Grundtvigs symbolverden " (titlen på hans disputats, den første litteraturhistoriske, 1950). Om Toldberg fristes jeg til at bruge Dickens' ord om kusken på London-diligencen: "Hans væsen var galop, hans måde at tale på: rask trav. Han var en ekspresvogn ..... Men han var langt mere end en ilpost. Med sit forcerede tempo som forsker forbandt han stor associations-rigdom og minutiøs omhu i studiet af Grundtvigs billedsprog, som han utrætteligt søgte at kaste nyt lys over.

Det nære samarbejde og venskab med disse tre forbundsfæller blev befæstet i sommeren 1947, hvor jeg under min studieorlov residerede ideelt i Nyborg Folkebiblioteks smukke mindestue for dets velgører, apoteker Albert Sibbernsen. På hans skrivebord stod et relikvie: H.C. Ørsteds kompas, der i 1820 gjorde ham verdensberømt, da han lagde en strømførende ledning over det og opdagede elektromagnetismen. Nu fik det dagligt selskab af Grundtvigs håndskrifter - en sammenstilling, der mindede mig om hans kendte ord i "Skolen for Livet ": "Mig blev det givet at opdage den store Natur-Lov for Aandens Virkning og Forplantelse... det mundtlige Ords ubetingede Nødvendighed til Livs Opvakkelse og Aands Forplantelse".

I Sibbernsens stue skrev jeg størstedelen af min disputats, og når jeg var træt af den unge Grundtvigs kæmpende og knortede teologi, slappede jeg af med at granske hans livsdrama og sammenstykke "Grundtvigs Erindringer», første halvdel af bogen, Steen Johansen og jeg udgav 1948.

I september 1947 var jeg sammen med Steen Johansen, Michelsen og Toldberg gæster i biskop C.I. Scharlings og stiftsprovst Villiam Grønbaks hjem i Ribe. Indbydelsen fra disse to "højærværdige og højlærde " gejstlige, der var kendt som højkirkeligt ${ }^{1}$ indstillede (sidstnævnte var Kirkeligt Centrums formand), havde

1. Dengang var "de højkirkelige" betegnelsen for "den tredie retning " i dansk kirkeliv, Mynster-Martensen-traditionen. Nu bruges benævnelsen om den stærkt katolicerende bevægelse, der siden 1958 udgiver tidsskriftet "Reformatio". 
vi måske modtaget med en vis skepsis, men den blev ganske gjort til skamme.

Vore to værter forskede Grundtvig med iver. Den elskelige biskop var ved at lægge sidste hånd på sit indgående arbejde om "Grundtvig og Romantiken (1947), og stiftsprovsten studerede Grundtvigs psykologiske tanker. Det blev tre ihukommelsesværdige døgn, hvor vi i bispegården alle redegjorde for vore studiemål og -områder, og derefter forhandlede om Grundtvigforskningens problemer. Vi var enige om, at fortsatte tværfaglige drøftelser ville gavne arbejdet med en så mangesidig indsats som Grundtvigs.

Søndag den 7. september, efter drøftelsen af aftenens emne, drejede debatten ind på ligefrem at stifte et selskab til fremme af samarbejde i forskningen og til udgivelse af dokumentarisk-videnskabelige undersøgelser af Grundtvigs værk. Den tanke havde jeg kort forinden drøftet med biskop Øllgaard på "arbejdskonventet ", hvor han foreslog at kalde et kommende årsskrift Grundtvig-Studier. Dette navn vandt bifald hos os i Ribe - klokken var ved at gå i slag.

Da standuret slog tolv den nat, var der højtid, som ved nytår, i bispekontoret, hvor litografier af Grundtvigs erklærede modstandere Mynster og Martensen stirrede - undrende? - ned fra væggen, flankerende Tuxens maleri af professor Henrik Scharling, biskoppens fader, der livet lang førte en bidsk polemik mod grundtvigianismen. I timen efter midnat vedtog vi at oprette et frit og åbent forum for Grundtvig-forskningen.

Næste dag, på Grundtvigs fødselsdag den 8. september, fandt det stiftende møde sted. Vi gjorde udkast til love og vedtog at søge kredsen af stiftende medlemmer udvidet med bl.a. biskop Øllgaard, professorerne Poul Andersen og Hal Koch og litteraturhistorikerne Gustav Albeck, Georg Christensen og Magnus Stevns. Toldberg blev sat i funktion som sekretær og jeg som redaktør af Grundtvig-Studier.

Ribemødet var ikke sammenkaldt med stiftelsen af GrundtvigSelskabet for øje. Beslutningen groede frem under indtrykket af den værdi, som det begyndende arbejdsfællesskab indebar. Men ville det nu også lykkes at interessere en tilstrækkelig stor kreds for vor plan?

De foreslåede medstiftere sluttede alle op, yderligere tilkom 
Th. Balslev, præst ved Vartov. Dér holdt vi konstituerende møde i januar 1948, hvor Scharling blev valgt til formand. Trods sit krævende embede, og under daglig kamp med sygdom, ydede han med sin forhandlingsåbne og inspirerende personlighed en virkelig indsats som brobygger mellem de tre hovedgrupper i vort selskab, den humanistiske, den teologiske og den pædagogiske. Han var i udpræget grad egnet til at bringe forskere med forskellig indfaldsvinkel på talefod. Efter hans død i 1951 sagde forstander Ernst J. Borup, Vartov, med rette, at Grundtvig-Selskabet ved Scharlings medvirken "blev løftet ud over det snævre retningspræg, det ellers kunne have fået ".

Januar-mødets deltagere erlagde straks et "stifterkontingent ", så den valgte kasserer, sognepræst Morten Øllgaard fik en kassebeholdning. Næstformanden, seminarieforstander Georg Christensen og jeg gik i Klareboderne og forhandlede med Gyldendals almægtige direktør, Ingeborg Andersen. Rygende - og bydende på Punch-cigar - tog hun sandelig Grundtvig-Studier på forlag, selvom hun klargjorde, at det var et vovestykke, der nok ville vise sig urentabelt.

$\mathrm{Da}$ vi foreslog et oplag på 2.000, replicerede hun: "Men kære dog! Et "lærd selskab» kan i Danmark højst påregne 250 medlemmer. Det ville De vide, hvis De var medlemmer af Holberg-Samfundet! Slige publikationer sælges sørgelig slet. To tusind, mine Herrer! Vi kunne sågar ikke engang afsætte visse af Georg Brandes' ting i hans sidste årtier i 750 eksemplarer!« Det endte dog med, at vort årsskrift blev trykt i 1.000 eks.

I januar udgik indbydelse til medlemstegning, efter at kredsen af stiftere var øget med bl.a. Kaj Thaning og højskolelærer Holger Kjar, Askov. Men endnu i august havde kun godt 250 tegnet sig, trods Toldbergs ildhu som hverver, også via presse og radio. Gyldendals nøgterne profeti overtraf vi dog en smule: medlemstallet var 333 ved første årsmøde 1948, hvor 500-600 blev sat som mål.

Hvad oplaget angår, fik Ingeborg Andersen ret: de to første årgange svarede sig ikke som forlagsartikel, og fra og med 1950 overgik Grundtvig-Studier i kommission. Direktøren sagde beklagende: "Ja, sådan et foretagende går jo ofte i stå efter et par år! " Men heldigvis levede årbogen videre. Tilbageskuen- 
de kan jeg med sandhed sige: Lovet være de legatstiftelser og fonds, hvis kilder i krisesituationer stedse mirakuløst åbnede sig!

Derfor kunne vi også klare udsendelsen af den lange række - 21 bind - Skrifter udgivet af Grundtvig-Selskabet, der startede i 1949 med min disputats og siden bragte endnu fire danske, af Toldberg, Michelsen, Thaning og Fl.Lundgreen-Nielsen, samt en svensk af Harry Aronson og en norsk af Sigurd Aarnes.

De 25 år, jeg bar ansvar i Selskabets forretningsudvalg, først som redaktør, siden som formand, blev så indholdsrigt et kapitel af mit liv, at jeg nu må lægge bånd på mig selv - ellers vil mine minder om trofaste værkfæller og udholdende medkæmpere løbe over alle bredder.

Eet navn er der, som må sættes med kursiv i selv det korteste rids af Grundtvig-Selskabets historie: Gustav Albeck. Endnu i talende stund står han, som 81-årig, i frontlinien, og dér har han været fra "løbet gik « i januar 1948: da holdt han dagens foredrag: "Omkring Grundtvigs Digtsamlinger", et prægnant præludium til hans hovedværk med samme titel (1955).

Aldrig før er disse digte, der blev sablet ned af samtiden, og næsten forbigået af eftertiden (til Hal Koch slog kontra i 1940) blevet så grundigt og givende undersøgt. Der kastes bestandig nyt lys over den fylde af erfaringer og visioner, som fostrede Grundtvigs digtning.

Albeck har varetaget redaktionen af Grundtvig-Studier uafbrudt siden 1953 - fra 1969 sammen med Michelsen, der 1972 også blev Selskabets formand - og i hele denne periode har han taget afgørende del i hele Selskabets virke med møder og seminarer, udgivelser og forskningsopgaver.

Ved vort første årsmøde talte Magnus Stevns om "Kingo-salmen og Grundtvig ". Han stod da på falderebet, nedbrudt af den snigende sygdom, som så tidlig hæmmede hans forskning. At han kom til at tale, hentet fra sygelejet - og tale som han gjorde var $\mathrm{i}$ virkeligheden et under. Med sit eminente kendskab til salmemanuskripterne forenede han sin dybe indlevelse så fint, at det ikke glemmes.

Jeg bad ham straks om manuskriptet til årbogen (hvor det kom 1949), men han ville gennemarbejde det forinden. Jeg modtog det først få uger før hans død, der afbrød hans ledende medvirken ved genudgivelsen af Grundtvigs Sang-Verk(1944ff.). Stevns hav- 
de betroet mig, at foredraget kun var "lidt vragrester fra hans strandede disputats " om Grundtvigs salmer. Hans enke gav Steen Johansen og mig adgang til hans efterladte papirer. Desværre var de mange optegnelser så fragmentariske, at vi fandt det urigtigt at medtage dem i vor udgivelse af hans samlede, trykte Grundtvigafhandlinger: Fra Grundtvigs Salmeværksted (1950). Siden har Selskabet oprettet Magnus Stevns' Mindefond, til fremme af studiet af Grundtvigs salmedigtning.

Fra starten stod det for os som et ønskemål at forberede en fuldstændig udgave af Grundtvigs forfatterskab, der skønnes at have et ligeså enormt omfang som Luthers. Det vil komme op på omkring 150 svære bind, hvis man medtager hovedparten af de uhyre mange utrykte prædikener, skrifter og forarbejder, som han har efterladt.

Det kgl. Biblioteks Grundtvig-arkiv er det største privatarkiv i Danmark fra det 19. århundrede. Edvard Lehmann aflagde "pligtvisit « i det, da han - con eleganza, men noget letvindt - skrev sin bog om Grundtvig. Han skottede her og der i et par af de 535 pakker, men tilbageleverede snarlig den støvede stak, idet han til bibliotekaren afgav sin rappe kendelse: "Dette er jo nærmest som en ørnerede, svær at komme til og bugnende fuld af skidt og møg - men: en ørnerede! «

Inden "den store udgave" kunne planlægges, måtte der foretages en indgående undersøgelse af disse læs af håndskrifter, for at datere og indholdsbestemme dem. Hvordan fik vi midler?

Et udvalg, der talte notabiliteter som vore to biskopper Scharling og Øllgaard, professorerne Hal Koch og Ernst Frandsen samt forstander Arnfred, gik til undervisningsminister Hartvig Frisch. Skønt syg, dødsmærket, lyttede han opmærksomt, også til os ivrige yngre hedsporer, udtrykte stor forståelse, ja sluttede med trumf, omtrent sådan: "Ja, det må nok være guld værd at grave $\mathrm{i}$ Grundtvig. Sågu'! Jeg er med på, at den Gamle nu kommer i de unges hænder".

Der kom store bevillinger. På Det kgl. Bibliotek iværksattes mikrofotografering af hele arkivet, hvorved man kunne forebygge ødelæggelse ved slid eller brand. Det var Toldbergs idé og ham, der gennemførte den, så forskere siden har kunnet studere papirerne via skærm. Samtidig tog han sammen med Albeck, Thaning og jeg fat på at tilrettelægge selve undersøgelsen og fastlægge ret- 
ningslinierne for den Registrant over N.F.S. Grundtvigs Papirer, som blev udgivet 1957-1964 i 30 bind (på over 7.000 sider).

Statens almindelige Videnskabsfond gav os midlerne til, i lykkeligt samarbejde med Det danske Sprog- og Litteraturselskab, at gøre "ørnereden " tilgængelig. DDSLS' formand, overbibliotekar, Dr. H. Topsøe-Jensen og dets ligeså erfarne administrator, Dr. Albert Fabritius, var fra start til slut uvurderlige fødselshjælpere ved tilblivelsen af dette mastodontværk. Det har vist sig at fungere fortrinligt som appetitvækker og uundværligt redskab for forskningen i den før så uoverskuelige fundgrube.

Sammen med professor P. Skautrup førte jeg tilsynet med udgivelsen, og det var en lyst. De tre tidligere nævnte "registratorer ", som jeg havde virket sammen med i første fase, fik hele fem kvalificerede kolleger: Steen Johansen, Michelsen, valgmenighedspræst Uffe Hansen (medudgiver af Grundtvigs Sang-Værk) og to fortrinlige yngre forskere, K. E. Bugge og Niels Kofoed, som begge siden skrev Grundtvig-afhandlinger, henholdsvis om hans pædagogik: "Skolen for Livet" (disputats, 1965) og om "Grundtvig som selvbiograf".

Kort før sidste bind af registranten udkom, smertede det os alle at erfare Helge Toldbergs bratte død under studieophold i London. Han var pioneren i ordningen af Grundtvig-arkivet, og ligeså megen tak tilkommer der ham for den uslukkelige energi, der førte ham til at søge samarbejde med forskere, der enten ud fra filologiske, litterære, teologiske, pædagogiske, psykologiske eller historiske interesser arbejdede med Grundtvig. Derfor var Toldberg som Grundtvig-Selskabets forste sekretær et "fund " - som skabt til at formidle det team-work, der frembragte Registranten, i håbet om, at dette værk - som Efterordet siger - ville "sætte sig rige frugter $\mathrm{i}$ de kommende generationers arbejde med Grundtvigs betydning for det danske folk ".

$\mathrm{Nu}$, hvor Grundtvig-Selskabet har passeret sin 40-års dag, er det en glæde at kunne konstatere, at det stedse har godtgjort sin eksistens-berettigelse. Rækken af Skrifter har fået værdifuld tilvækst - i det sidste årti er f.eks. Flemming Lundgreen-Nielsens værk: "Det handlende ord " (1980) søsat (så at sige) som en forskningens Dreadnought, og der har aldrig været mangel på lødigt stof til Grundtvig-Studier.

Til stadighed er nye forskere trådt til. Her må jeg særlig nævne 
bogen "For sammenhængens skyld" (1977), hvori en række af professor Chr. Thodbergs elever behandler forholdet mellem Grundtvigs prædikener og hans salmedigtning. Et af vort Selskabs mål: samarbejdet mellem forskere, er her ført ud i livet på smukkeste måde - ligesom ved Registrantens udarbejdelse. Dette teologiske team-work ved Århus Universitet har som bekendt afsat en frugt af format: Chr. Thodbergs 12 binds udgave af prædikenerne 1822-26 og 1832-39 - de år, hvor Grundtvigs salmedigtning for alvor tog fart. Vor første professor i praktisk teologi har gjort sit fag dobbelt ære ved både at inspirere og skole ikke mindre end 16 studenter til dygtige medarbejdere med gengivelse af teksterne og ved selv, $\mathrm{i}$ indledningerne til de enkelte bind, at give os ariadnetråden til forståelsen af og fordybelsen i Grundtvigs forkyndelse og hans Sangværk.

Jo, vi bedagede kan med fuld fortrøstning sige:

For de gamle, som faldt, er der ny overalt, de vil møde, hver gang der bliver kaldt. 